\title{
Sustained-Yield Forest Management: The View from Sweden ${ }^{1}$
}

\author{
by
}

Björn Hägglund ${ }^{2}$

\begin{abstract}
Sweden is a small but quite active forest country. Occupying about $0.6 \%$ of the world forest land area it holds about $15 \%$ of the international wood products market. The standing volume of forests has increased continuously since about the year of 1900. Many factors have contributed to this positive development. One is Sweden's conversion from a poor underdeveloped agrarian country to a modern industrial one. This meant a tremendous increase in agricultural efficiency and thus an important release of land which could be shifted from agriculture to forestry. But another reason for increased forest resources was and is the belief in the importance of having good forests in a remote future. The sustained or even increased yield concept is a part of this belief, materialized most of all as a more intensive silviculture.
\end{abstract}

\section{Résumé}

La Suède est un petit pays, mais très actif sur la scène forestière. Les terres forestières correspondent à $0,6 \%$ du domaine forestier mondial, et comptent pour près de $15 \%$ du marché international des produits forestiers. Le volume sur pied des forêts s'est continuellement accru depuis les années 1900. Plusieurs facteurs ont contribué à ce développement positif. L'un d'entre eux est la transformation de la Suède de pauvre pays agricole sous-développé en pays industriel moderne. Cela s'est traduit par un accroîssement formidable de l'efficience en agriculture et par le fait même par une importante disponibilité de terres qui pouvaient être affectées de l'agriculture à la foresterie. Mais une autre raison de cet accroîssement des ressources forestières a été et demeure la conviction dans l'importance d'avoir de bonnes forêts dans un avenir lointain. Le concept de rendement soutenu et même accru fait partie de cette conviction, étant réalisé surtout par une sylviculture plus intensive.

\section{From Sustained Yield to Sustainable Development}

Sustained yield means in a traditional sense that forestry is performed in such a way that the future potential cut never falls below the actual cutting level. This is not a very aggressive forestry strategy. First it only takes volume yield into account. Quality and value are other important characteristics of forest yield. Secondly, forestry on sustained yield basis could be performed at a very low yield level. For instance, a natural forest ecosystem at a mature stage could be said to work on a sustained yield (equalling zero) level.

In Sweden we have worked in such a way that we actually got an increased yield volume. This will, according to our intentions, also be the case for the coming 100 years. However, even if we increase yield it is not at all certain that we increase value. Doubt arises concerning wood quality. Many people believe - and probably they are right - that the new relatively fast-growing man-made forests will produce saw timber inferior in quality to the natural old-growth.

Another important forest characteristic is its environmental values. As today's forestry does not produce today's forests the environmental values of our forests will at least change in the future.

To include values such as wood and environmental quality in forestry strategy we have to go from the traditional sustained yield idea to the "sustainable development" concept recently presented by the Brundtland Commission. A tentative interpretation of this concept for forestry is as follows.

\footnotetext{
${ }^{1}$ Paper given at the CIF Annual Meeting, Kananaskis Village, Alberta, October 18, 1989. ${ }^{2}$ National Board of Forestry, Jönköping, S-55183, Sweden.
}

Forestry shall be performed in such a way that the total welfare effects of forestry activities never decreases in the future. These welfare effects include benefits from volume yield and wood quality as well as from environmental factors. Many of the factors determining the welfare effects are difficult to quantify and must be formulated as simple rules of thumb such as "forestry shall not lead to the extinction of plant and animal species". The "sustainable development" concept is more a matter of ethics and a long-term wish for man's survival on earth than of economics. Traditional forest economics, based on standard investment theory in its simpler form, has more or less finished its role in the formulation of long-term national forestry strategies. And even if theory exists for handling the complex decision problems of today we have a long way to go to find a purely rational way to formulate long-term forestry strategy.

Actually it is doubtfull whether any purely rational forestry strategy decisions have ever been taken. When the Swedish pioneers in afforestation started to plant trees on the vast heather of southern Sweden, they probably never made any Faustmann formula investment calculations. Because if they had done the calculation, they had never done the planting. And the same is true today.

The further development of long-term forestry strategy will mean a switch from "increased yield" to "sustainable development". The latter concept might well include the first. It will be up to ourselves whether the new strategies are formulated within or without forestry. But I think we have a good case, managing a renewable resource created by the sun, some carbon dioxide and water. And we are not that far from the Brundtland Commission concept in today's Swedish forestry. Let us have a look. 


\section{The Goal and How to Formulate It}

The goal of Swedish forest policy is formulated as follows. "Land suitable for forestry and not used for agriculture or other more important purposes should be used for forestry. This forest land should be managed to give a high, valuable and sustained yield of industrial timber. This should be done with due consideration to environmental and other common interests."

In more tangible words this means that forestry should be the dominant land-use on about $60 \%$ (23 million ha) of Sweden. Forests should be managed for a sustained yield of at least 75 million $\mathrm{m}^{3}$ per year, comprising about $85 \%$ softwood out of which a considerable part is high quality saw timber.

The factual basis of this policy is a series of state investigations on forestry. From the 1930's, these investigations almost always included some forecasting of future forest growth and calculations on sustained yield at different national forest management programs. These forecasts always have been based on the Swedish National Forest Survey, an indispensable basis for all serious considerations about forestry on a national scale.

\section{Consensus is the Word}

Private persons own $75 \%$ of the forest land in Sweden (25\% private companies, $50 \%$ farmers). To succeed, forest policy must be formulated with active participation by the land-owners. However, to reach political solutions, agreement is necessary with trade unions as well as environmentalists. So far, an adequate consensus has been reached on Swedish forest policy. This has led to strong decisions by the Swedish parliament which have been well respected by the forest owners. However, some discussion continues.

Even if the forest owners support the basic goals of the forest policy, their representatives argue strongly for deregulation of forest policy means, for example, a simpler forest law. These ideas are supported by the conservative opposition parties. However, this argument is counteracted by another, saying that forestry is a rough and exploiting business that should be put under stronger control by society. I personally believe that the latter movement, formulated and pushed forwards by the environmentalists, represents the stronger force in the long run. It represents a further step not necessarily forwards - in the irregular development process between sustained yield and sustainable development.

\section{The Forest Policy Implementation Tools}

Many forest policy formulations have ended up as beautiful pieces of paper and nothing more. The relative success of forest policy in Sweden is largely owing to the fact that the tools for implementing forest policy are effective and that appropriate resources are used for this purpose. These tools are described briefly below.

\section{Organisation}

Forest policy is implemented through the Swedish Boards of Forestry Organisation, comprising 250 forest districts, led by 24 County Boards of Forestry which in turn are led by the National Board of Forestry. The Board of Forestry is an independent authority, led by the Department of Agriculture. The Boards are completely separated from the Swedish Forest Service, which manages all state forest land and acts like any other forest company. All forest land, including state land, is supervised by the Boards of Forestry.

\section{The Forest Inventory}

The state financed forest inventory is conducted on two levels in Sweden. The National Forest Survey is, as mentioned above, an indispensable support for strategic forest policy decisions. For operational forestry planning, the General Forest Inventory (GFI) is conducted. The GFI is a traditional stand inventory based on ocular estimations. The GFI covers $10 \%$ of all private forest land each year. Other landowners (state, companies) have to deliver similar data as the GFI to the Forestry Boards. GFI data form the basis for the work on the forest districts. By means of these data stands in "outlaw" condition are identified, as are needs for extension services. It is impossible to implement forest policy if you do not know forest conditions.

\section{The Forest Law}

The Forest Law, first implemented in 1903 and successively elaborated to the latest version (1979), is the most fundamental part of the forest policy implementation tools. It states that:

- forest land must be regenerated after final cut;

- precommercial and commercial thinning must be performed in very dense stands;

- too young stands must not be clear-cut;

- there are certain upper and lower limits for the final cut on a farm during a ten-year-period; and

- environmental considerations must be incorporated into forest operations.

There are additional rules. One comment on the environmental concern is that the forest owner has to bear costs of environmental measures up to about $10 \%$ of the net income from the cut. If more environmental consideration is demanded, the state has to pay the land owner for lost income.

The Swedish Forest Law is quite precise concerning the demands on the forest owner. The law sets, for example, minimum requirements for surviving plants per ha in the regeneration work. It is this preciseness that makes it possible to really use the law in the field. It is possible to say whether a certain stand meets legal requirements or not. Each year the forest district staff finds about 30000 stands where something must be done according to the law. They tell the forest owner, and normally the necessary operations are performed. Only in about 50 cases per year do the Boards have to go the courts to get the forest operations done.

\section{Subsidies}

Forest owners can get subsidies covering part of the cost for long-term investments in forestry where the expected return is low. Subsidies are also used to stimulate forest owners to cooperate in, for example, a forest road building project. Recently it also became possible to use them for measures promoting nature conservation. The subsidies are financed by means of a silvicultural fee, paid by the forest owners themselves.

\section{Extension}

Extension service comprises a variety of important activities, including mass-distributed folders and magazines, 
lectures and courses for groups of forest owners as well as individual forestry counselling.

\section{Commercial Services}

The Boards of Forestry offer many commercial services to the forest owners. Among these are the selling of plants, operational (relief) work and making forest management plans. Earlier these services were of little commercial interest to private enterprise, but today there is tough competition for instance in plant production and selling.

\section{Other Means}

The Swedish forest policy is also integrated into other policies such as those concerning taxation, the labour market, regional development, environmental legislation, land trading, education, and research. The aim is that these policies shall help attainment of the forestry policy goals. At the same time forestry shall support for, example, regional development.

\section{The Future}

How will the Swedish forest policy look in say ten years? Of course nobody knows. But extrapolating from existing trends, we shall face a continued change towards the sustainable development policy. The change will mean greater consideration of the environmental values of the forest. Is that bad or good from the forestry point of view? Well, intuitively we would say that it is bad. Foresters almost always react negatively to demands from the environmentalists. This is natural in the sense that environmental concern is a common interest conflicting with the interests of private landowning. But the same negative reactions occur among foresters working on state lands. I believe this must be changed. The pollution of the atmosphere, acidification of soils, leaking of nitrogen and metals, etc., should teach us that the carrying capacity of the forest ecosystem has been reached in much of Western Europe. And the power that could help us to cope with these threats is the same one that we criticize for interfering with practical forestry in an incompetent way, namely politicians with a strong dedication for environmental concerns.

So, there is only one solution. The future development of forest policy must take place in a consensus process involving all relevant interests - politicians, land-owners, trade unions, environmentalists and professional foresters. It will demand an open-minded attitude to new questions from the foresters. If this can be achieved, the foresters will become the big winners. If we look upon ourselves as managers, not only of wood production, but of total outcome of forestry we shall have added greatly to the forester profession. And we shall no longer be regarded as grit in a process that will continue whether we are on the train or not.

\title{
Les Ressources en bois du Canada Conférence nationale
}

\section{Du 3 au 6 juin 1990, Conference Centre, Victoria (Colombie-Britannique)}

De nombreux conférenciers de tout le Canada parleront de l'état actuel des forêts canadiennes, des changements qui les affectent et de l'approvisionnement en bois à long terme.

Des présentations techniques porteront sur des études de cas et sur des façons innovatrices de calculer l'accroissement et le rendement, de formuler la réglementation forestière, d'assurer l'aménagement intégré de la ressource et de prévoir l'approvisionnement en bois.

Pour obtenir des renseignements sur l'inscription, le programme de la conférence, la séance d'affichage, le logement ou le transport, veuillez communiquer avec la personne suivante :

\author{
Mme Penny A. Walker \\ Secrétariat \\ Les Ressources en bois du Canada \\ Inventory Branch, Ministry of Forests \\ 1450 Government Street \\ Victoria, C.-B. V8W 3E7 \\ Téléphone: (604) 356-7185 \\ Télécopieur : (604) 387-5999
}

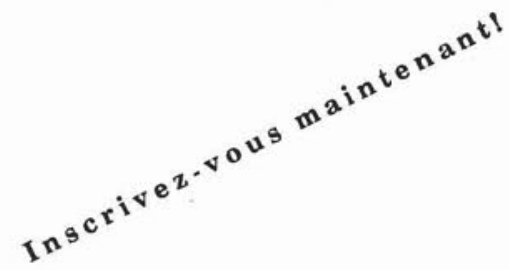

Parrainée par Forêts Canada et le ministère des Forêts de la Colombie-Britannique.

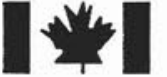
Forêts
Forestry
Canada
Canada

MINISTRY OF FORESTS 